\title{
Examining the Policies in Turkey That Have Been Implemented during the Structural Reform Process from the Standpoint of Growth-Unemployment
}

\author{
Metin Bayrak $^{1} \&$ Ömer Esen ${ }^{1}$ \\ ${ }^{1}$ Department of Economics, Faculty of Economics \& Administrative Sciences, Ataturk University, Turkey \\ Correspondence: Ömer Esen, Department of Economics, Faculty of Economics \& Administrative Sciences, \\ Ataturk University, 25240, Erzurum, Turkey. Tel: 90-442-231-2116. E-mail: omeresen@atauni.edu.tr
}

Received: March 26, 2013

Accepted: April 10, 2013

Online Published: May 21, 2013

doi:10.5539/ijef.v5n6p134

URL: http://dx.doi.org/10.5539/ijef.v5n6p134

\begin{abstract}
In this study, the change and transformation that has been experienced in the Turkish economy within the progress of structural reforms are being probed and by breaking down the relationship between economic growth and unemployment in a dynamic manner, the reasons that the consistent growth rate that has been reached within the structural reform process had such a low level of impact on creating employment and decreasing unemployment are being discussed. In line with this aim, as is discussed in the literature, whether or not there is a fraction in the relationship between the economic growth and unemployment was tested using Zivot-Andrews (1992) Structural Test and in this scope, the work was examined by dividing it into two sub-periods as 1980-2001 and 2002-2011. The direction and the size of the relationship between the given variables have been researched by utilising Johansen co-integration and error correction model.
\end{abstract}

Keywords: economic growth, jobless growth, unemployment, structural reforms, structural break

\section{Introduction}

The concept of economic growth, which is in the centre of the economic policies that are implemented in developed or developing countries, which are also among the most widely discussed and researched topics in every period in the historical evolution of economy, by its primal meaning, can be expressed as the increase of a country's capacity or amount of producing goods and services in a certain period of time. From this viewpoint, the economic growth of a country means a constant increase of that country's real GDP (O' Sullivan \& Sheffrin, 2006). In other words, growth can be described as the increase in the resources (capital) per capita that constitute the economy or rising the efficiency of those used resources (Mundlak et al., 1989). As far as it can be understood from the given definitions, economic growth is a long term concept and is related to the increases in production capacity or amount.

In the literature of economy, there are two methods known to exist regarding growth. The first is increasing efficiency and the other is raising the amount of input that is used in production. In general, in the case that economic growth occurs in an economy, it is expected that following the increase on the production scale, employment increases and consequently unemployment decreases. From this point forward, considering unemployment merely as a growth problem and the idea that the unemployment problem would be resolved when growth occurs constitutes the general opinion. As has been experienced in many developed and developing countries, Turkey set out a consistent economic performance in the post-2001 period. However, in parallel to this fact, it has also been observed that the unemployment problem failed to be solved; on the contrary, it actually became bigger. In the literature, the approach, formulated as the anticipated relationship between the economic growth and the unemployment is now weakened or entirely severed, started to take place as the jobless growth or growth without employment (Datt, 1994; Padalino \& Vivarelli, 1997; Caballero \& Hammour, 1998; Bhattacharya \& Sakthivel, 2004; Telli et al., 2006).

Unemployment, rather than being a solely economic problem, is also a complex problem that has multi-sided social reflections with both social and individual aspects. Unemployment, within the global crisis, is no longer a problem in less developed or developing countries only, as it is becoming an extremely crucial common problem that occupies the agenda of all world economies. In Turkey, many macro-economic problems, notably 
unemployment, became the main indicators of the economy with the globalisation process intensified starting in the 1980s. The Turkish economy included itself in this transition without preparing a competitive environment in the goods and services markets, without bringing itself to force by downsizing the public sector and without making the necessary regulations and arrangements. In contrast, Turkey lived through those years in a course where short term economic decisions were being made and where internal vicious cycles of political struggles were being experienced. As a result, when the 2000s arrived, due to the decline of the financial markets, and the emerging unstable economic growth trend with its ebbs and flows, some serious economic problems emerged in the $1990 \mathrm{~s}$ and at the start of the $21^{\text {st }}$ century. Within this context, a necessity emerged to make the structural reform at the required fields in order to overcome the instabilities that appeared in microeconomic balances immediately for the Turkish economy to reach stability and to achieve a sustainable growth trend,. In response to this necessity, in the post-2001 period (Note 1), some structural reforms and regulations, which were aimed at providing rapid stability to the economy and aimed at conquering the sustainable growth trend, were actualised. The economic and political stability and consistency that was achieved with this process enabled the Turkish economy to progress towards consistent economic growth. However, despite those positive indicators experienced in the Turkish economy, it is also observed that such a course of growth failed to be effective regarding increasing employment and decreasing unemployment (World Bank, 2006).

From the viewpoint of the necessity not to consider unemployment as a growth problem or a problem that emerged due to instable growth, the reality that even as the result of Turkey's recent stable growth progress, sufficient levels of employment could not have been created, therefore unemployment did not decrease. The case that appeared in this progress and that is felt vividly is regularly debated in economic circles. In contrast to the common idea that indicates that the economic growth increases employment and decreases the unemployment rate, the empiric studies, which were conducted recently, question the relationship between those two macro-economic variables (Kılıç, 2003; Yılmaz, 2005; Yuceol, 2006; Ataman, 2006; Ceylan \& Şahin, 2010). Most of the previous studies, clearly there is a delinking of economic growth and unemployment in the post-reform period.

In this study, the concept that whether the policies that have been put into effect at the beginning of the $21^{\text {st }}$ century, although they can be traced even further back, which contain structural changes in their very cores, can solve the problems in the economy and can explain the dilemma between growth and unemployment, is analysed. In this direction, by making a dynamic analysis of the relationship between economic growth and unemployment, the reasons why a stable economic growth that has been reached in a structural reform process cannot lower the unemployment rate to the anticipated levels, will be researched. Within the scope of this concept, the works that analyse the relationship between economic growth unemployment will be examined as a matter of priority. In the second part, the growth performance of Turkey depending upon the structural reforms and its relation to unemployment will be explained in theory and then by analysing this relationship from a macro-economic angle; a general evaluation of the results will be conducted. In the final part, the results of the analysis and their compliance to the literature will be debated.

\section{Literature Review}

In literature it is widely acknowledged that a stable economic growth decreases unemployment by providing new job opportunities in economies with established legal and institutional backgrounds which gains a more effective and competitive structure to the sectors (Aghion \& Howitt ,1994; Seyfried, 2005; Christopoulos, 2004). In the short run, generally there is a delinking of economic growth and unemployment in post-reform periods. But as time pass by, the reversal of this situation is expected.

In relation to the discussions centered around the relationship between economic growth and unemployment, Gordon and Clark (1984) argue that any economic growth without the capacity to create new job opportunities can possibly have no effect in decreasing unemployment hence they claim that not every economic growth can actually have a positive effect in the ratio of unemployment. Aghion and Howitt (1994) allege in their study exploring the effect of economic growth on unemployment in the long term that the rises in economic growth are influential in creating new job opportunities by increasing capital incomes and also effective in shortening the job-finding process.

Amongst all studies dwelling on the weakened connection between growth and employment, Bhattacharya and Sakthivel (2004) in the study that comparing the employment behaviour in the pre and post-reform period, found that while there has been a soft acceleration in the economic growth rate in the post-reform period, there has been a sharp deceleration in the employment growth rate during the same years. Scarpetta (1998) in his research that deals with the effects of structural reforms on labour market conditions, argues that structural reforms have 
succeeded in curbing unemployment, but the reform process needs to be pursued consistently for a long period to bear fruits. In another relevant study Calmfors and Holmlund (2000) asserts that labour-market reform reduces unemployment and lead to higher growth in the long term.

Amongst studies that deals with Turkey on the topic, Kesici (2010) who focuses on relationship between economic growth and labour market during high growth period of 2002-2007. Here he concluded that while there has been improvement in some areas of the economy, this situation was not observed in the labor market. The increase in employment has been limited and increase in the unemployment rate has continued In this process. Ataman (2006) in his study covering the period between 2000-2005, analysed the relationship between economic growth and employment in Turkey. According to the results of the relevant analysis, it was determined that the restructuring of the Turkish economy caused very important change on level of economic growth, while the high level of growth rates made only limited contribution to the solution of the unemployment problem. Acar (2008) examined the effects of structural transformation in Turkey Economy. The findings suggest that the increase in unemployment problem is directly related to structural reforms in Turkish economy which has been going through a very dynamic process in recent years.

\section{Discussion of Jobless Growth in the Post 2001 Period in the Turkish Economy}

With the structural reforms made in Turkey, the structure of the economic growth as well as the employment concept displayed significant changes in 2000s. The fact that the authorities considered unemployment merely to be a problem of growth and the idea reflecting that; in the case of that economic growth occurs, the employment problem is resolved prevented the development of a comprehensive solution strategy to be developed against the unemployment problem until the structural reform process (Ataman, 2006). In this new era, structural regulations, which were aimed at providing long term solutions by delving deep into the problems, which strengthened the institutional infrastructure of the free-market economy in the Turkish economy and which were intended to enable the economic actors to operate efficiently, were made in macroeconomic areas. Nevertheless, although the Turkish economy has secured the financial discipline, developments in inflation and interest rates have been recorded and a stable rate of growth has been reached, it is also observed that the economy has been ineffective in increasing the employment rate and decreasing joblessness.

As a result of certain structural reforms and regulations made during the post 2001 crisis era, Turkey has grasped an economic growth trend and therefore created some level of employment. Despite this, the rate of unemployment has not decreased in parallel to the growth and climbed up to a level even preceding the pre-crisis period. (Note 2) Many reasons behind the ever increasing unemployment rate despite the stable economic growth and raising level of employment can be given. Apart from the fact that the employment problem is projected as a mere growth (or non-growth) problem and the partly true idea of the demand for employment will be increased in conjunction with the growth, this does not constitute a sufficient base for a solution. Therefore, to reach a solution, displaying the nature of unemployment and discussing whether or not in a long term economic trend every economic growth cycle decreases unemployment is essential.

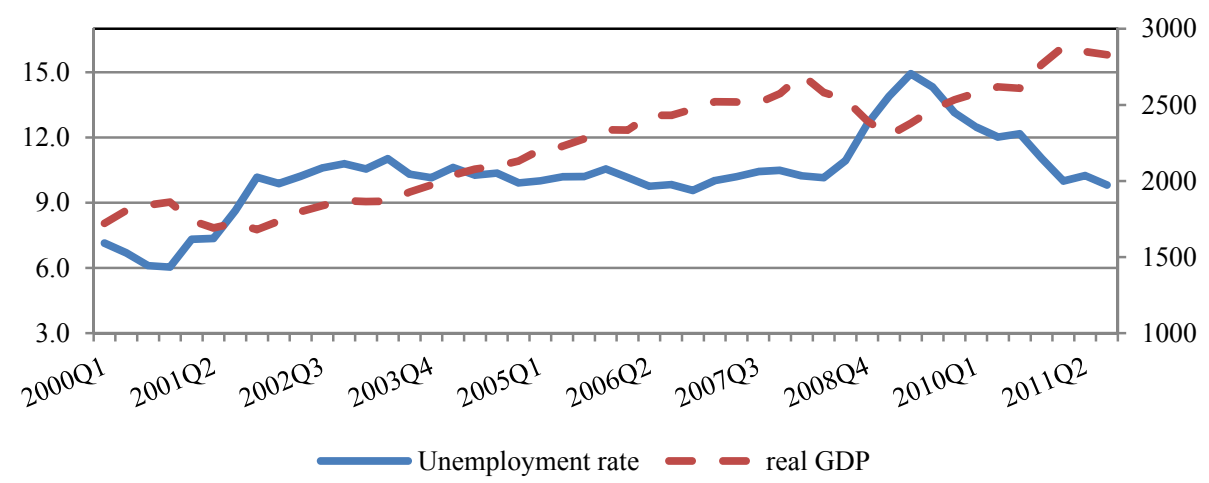

Figure 1. Economic growth - unemployment relationship, 2000-2011

The relationship between the unemployment rate, which is composed after being cleansed from the seasonal characteristics of Turkey and the economic growth sequences, is indicated in Figure 1. According to this, when the growth performance and unemployment rates of Turkey in the 2000s are observed, it is revealed that the unemployment rate significantly increased in the term of 2001-2001 with the influence of the global financial crisis and have fluctuated in a close pitch (9.9-10.2) from the first quarter of 2002 until the period where the 
effects of the 2008 global crisis began to appear. In addition, the unemployment rate entered into a rapid increase trend again with the effects of the global financial crisis, experienced at the end of 2008 and as of the end of 2009 , with the economy regulating itself back onto a stable course, it was experienced that the fluctuations of the unemployment levels left their places and returned to their former levels. However, it is also noted that the economy of Turkey began a fast course of economic growth after 2001 and between the years of 2001-2008 that encompasses the pre-crisis period, registered a 7\% annual growth rate. The 2008-2009 period with the devastating impact of the 2008 global crisis, were the years when the economy recessed and unemployment rates increased. It is well noted that Turkey failed to decrease the level of unemployment even in the 2002-2007 period during which it grew significantly, becoming even higher than the unemployment levels during the crisis period. However, in the post-2008 crisis period, it is also seen that the relationship between growth and unemployment differs and the economic growth, which occurred in relation to recovering the Turkish economy in the post-crisis period, reflected upon the unemployment figures and consequently bringing them down.

\subsection{From the Structural Reforms to Economic Growth}

When we take an overall look at the Turkish economy, it is observed that the Turkish economy had a fast transition from being a structure where the capital stock was low and the decisive factor for the economic decisions and the distribution of the resources was the state, to a structure with an increasing amount of capital stock where the impetus of the economy is the private sector. These transition processes started in particular with the liberalisation, foreign expansion and export oriented growth strategies implemented in the 1980s and the applications towards the integration with the globalising world economy and continued in the 1990s with financial deregulation policies. However, Turkey was caught off guard against the globalisation process, which further accelerated in the last quarter of the $20^{\text {th }}$ century. Turkey included this process without transforming its macro-economic equilibrium into a reliable status and without actualizing the structural measures that are required to compete with the ever globalising world. Turkey, along with the chronic inflation fluctuating in high levels, experienced an instable growth process with high interest rates pulled up by the financing needs due to the disrupted financial discipline and because of the negative effects of this phenomenon. In 2000s, it is seen that the financing instabilities played a substantial role in the very high levels of inflation and the fluctuations in the growth, as well as the high susceptibility of the growth potential to external shocks. In this context, the necessity to implement certain structural reforms in some required areas had emerged in order to stabilise the Turkish economy immediately and in order to overcome the faults that were experienced in macroeconomic equilibriums for putting the economy in a sustainable growth trend.

Among the policies and measures, those that are made within the scope of the structural reforms, the regulations made in the agricultural sector come forward. In addition to these facts, the output of the agriculture sector remained considerably lower than its level of production that could be reached by its current resources, losing its power of competition in the international arena, also the income levels of the producers remained lower than the expected levels due to the fact that faulty subvention policies rendered the implementation of some regulations necessary in this area. Due to the result of the practices in addition to all of these factors, the subventions that were provided to the producers loaded heavy strains on the extra-agriculture sectors formed an unjust structure that can also be seen as an another important reason. Also upon the implemented policies, the price indicators of the market were disrupted and therefore had a negative impact on price stability. While the share of the supports made prior to the reforms towards the agriculture sector within the GDP was $3-4 \%$, the very same ratio was approximately $1-1.5 \%$ within OECD countries. This situation that was based on the populist decisions solely made after politic concerns and ill planning put further strains on the non-agricultural sectors (Cakmak et. al,1999). In addition to the fact that the support policies, implemented prior to the Agriculture Reforms, were far from solving the then-current problems, simply because they increased the financing burden on public finance, and formed pressure on the inflation and interest rates, they had prevented the development of the economy for many years. Within this context, the most important reform movement made in the sector was cancelling the credit subventions provided by state owned banks. The effects of the cancellation of the subventions were eased by the steep dive of the credit interest rates including the agricultural credits, all thanks to the macroeconomic progress (IMF Letter of Intent, 22/06/2000). By rendering the agriculture sector able to operate much efficiently due to the regulations made in this field and due to the end of the supporting policies, which were nothing but a burden on the public finance and which were regarded as a political tool, significant steps were made towards securing the financial discipline in the public sector.

The problems within the social security system are also one of the structural problems of Turkey or, in other words, they are one of the predominant factors behind those structural problems. Providing services in the pre-reform era under different institutions such as the Social Security Institution (SSK), State Pension Fund 
(SPF) and the Social Security Organisation for Artisans and the Self-Employed (Bağ-Kur), brought up injustice amongst the security receivers within the scope of rights and duties and, at the same time, lead to numerous difficulties regarding control and financial structure. In addition, a great deal of financial burden was also brought upon the public finance by early retirement implementations. At the same time, in this period, $62 \%$ of those who retired were under the minimum retirement age of 58-60. While four insured people should finance a retiree for a sustainable social security system, this registered at the levels of 1,9. According to the comparisons between OECD counties, Turkey had been placed among the longest retirement pension paying countries for several years (Ministry of Labour and Social Security, 2008). Therefore, on one hand the social security institutions were deprived of the required premiums, while on the other hand they had to pay retirement pension for a longer period than they receive relevant premiums. This situation became one of the most important factors behind the constant deficits in those institutions. Within the context, the problems that were experienced not only effected the said institutions but also the financing problems that the social security institutions experienced created pressure on public finance and therefore effected the other economic indicators in a negative direction, inflation being the most prominent. Also, due to the fact that a significant part of the actualised premiums could not be collected, premium income of those institutions stayed at low levels therefore increasing the burden on the budget. As a result of the inspections, it was predicted that unless the necessary reforms were implemented, the size of the social security system deficit within the GDP would climb to 16\% in 2050 from a level of 3\% in 1999 (IMF Letter of Intent, 09/12/1999). Within this context, merging the SSK, SPF and Bağ-Kur under one single structure, in addition to equalising the rights and duties of the security, also enabled a single financially sustainable retirement security system to be established. As a supplementary implementation, the minimum retirement age for men was increased to 60 from the former 43 and to 58 for women from former 38, while the base and cap salary that form the base of calculating the premiums also increased.

Another vital point behind providing the macroeconomic stability and registering a consistent grow rate was the regulations made in the public area. In the pre-reformist period, the habit of making extra budget expenditures by lateral transaction applications such as extra budgetary funds, task damages and the inability to use resources in an efficient way increased the levels of fraud and corruption. Also, due to fact that the services and goods provided by the public administrations failed to meet the expectations of the people, trust in the administration became corroded and the fact that financial discipline could not be secured caused budget deficits, therefore disrupting the overall growth process of Turkey. The most important regulation made within this scope was to shut down funds that cause dissipation by disrupting the discipline in expenditures and which could not be audited sufficiently and efficiently due to the fact that they were out of the Grand Assembly's control. Conversely, legal regulations were put into effect for the sake of transparency and accountability in order to inform the public how the resources that are gathered from the people are spent.

The overall health of the banking system is essential for the economy of a country. The structure of the banking sector has an important influence regarding whether or not the crisis will pop up in addition to being a an indicator of living through the crisis periods lightly or regarding the crisis not becoming too severe. For such reasons, while the economies of the developed countries where the banking sector is regulated by sound rules are rather resilient against the crisis', just like the Asia crisis and the crisis that Turkey lived through, showed that the effects of such crisis' were felt much more strongly in economies that gave insufficient importance to banking regulations. Within this concept, the most important step towards Turkey's target of securing the macroeconomic stability and reaching up to a consistent, sustainable economic growth was the regulations, preceded within the axis of "Banking Sector Re-Organization," The Turkish Banking system in the pre-reform period was a structure that was far from the traditional banking activities, where the rights of the accounts holders were not protected adequately, where the sufficient and efficient inspections could not be carried out and which was far from being competitive. This status caused the disruption of the macroeconomic stability and made the economy weak against the sudden changes in the international finance markets. The mismanagement of the public banks and designating different tasks to them other than their primary roles in particular cased the increase of the receivables of duty damages such institutions from the treasury having negative effects on the economy over the budget. As a result, some legal and institutional regulations, which increased the efficiency of the inspection as well observation, which enabled the sector to be much more efficient and competitive, were put into effect. The most important reformist move here was to establish the Banking Regulation and Supervision Agency (BRSA) as an independent authority. For that matter all kinds of transactions and applications that could jeopardise the rights of the account owners and that could inflict substantial damage to the economy could be prevented and the decisions and measures that were required for efficient operation of the crediting system, could be taken rapidly and applicably. Also, there had been no preventive measures against the public banks to be assigned with various tasks that would be reimbursed by the treasury. However, as a result of the regulations, the public banks were 
also rendered subject to the "Banks Law and Mercantile Law" just like any other bank in the sector. (Note 3) One another important point from the viewpoint of the indebtment discipline is the passing of the "Public Indebtment Law" and the clear securing the independence of the Central Bank. In particular, cancelling the ability of the Central Bank to provide short term advances to the treasury enabled the Central Bank to implement an autonomous monetary policy. In this way, the increase of the inflationist pressure was averted and a long line of incorrect policies were prevented. For such reasons, the sector, via the regulations made in this area, was transformed into a healthier status and was enabled to make more contribution to the finance for economic growth.

In general, with the structural reforms that were put into implementation as the result of its crisis experiences, Turkey achieved considerable success in its economy. In this period, while securing high and consistent growth, it also succeeded in bringing inflation down to single digits. At the same time, Turkey got rid of the disease of financial indiscipline that threatened economic as well as political stability and which it had struggled to solve for many years and the budged discipline was also widely provided. By the regulations, the demand for the debts of the state that became chronic were also largely reduced. At the same time, the banking sector, which is pivotal both for the financing of the growth and the strength of the economy, was restored to a healthy state by the regulations and the supervisions and went through a serious test with the recent crisis.

\subsection{From the Economic Growth to Jobless Growth}

When the increased total demand, as a result of the realisation of the consumption expenditures in the post-stagnation of crisis periods that had been previously postponed, is met with the production increase, a boost in the growth is expected. However, the wages of the labour do not increase immediately in parallel with the production increase. In such a period, the manufacturing sector responds to the increasing demand not by utilising additional workforce but by further using the current labour. This may bring about rapid profitability and thus growth to the manufacturer (Fulco, 1984; Marelli et al., 2010). However, growth provided in such a way has no impact on the decrease in unemployment even in the short term. However, with both the local and global scale crisis' that are experienced in the economies, the manufacturers, by lowering the labour cost, may choose to increase production by the current workforce for the sake of preserving the current competitive force or in order to bring their cost structures up to the levels that enable them to compete in national or global areas. In this period, the enterprises continued production by putting their labour force at their disposal to work further and did not think kindly of utilising new labour until a point where their own labour found it too difficult to carry on the operations of the said enterprises further (Boyer \& Petit, 1981; Havlik \& Landesmann, 2004; Belorgey et al., 2006; Marelli \& Signorelli, 2010). In this way, the enterprises can minimise their costs by increasing the amount of production per worker (labour productivity) thus realising more production and more revenue with the same workforce and avoiding certain costs that would otherwise surface in the case that an additional worker is employed such as security premiums, only by paying the overtime wage. Thus the increasing the labour productivity may conflict with the increase of employment (Havlik \& Landesmann, 2004). In this case, increasing the efficiency leads to rapid growth. However, the increase in workforce efficiency may, even in the short term, destroy employment opportunities and thus increase unemployment (Boyer \& Petit, 1981). In addition, the low employment ratio in an economy indicates that only the most efficient workers are included in the production process and suggests that an increase in employment would mean the employment of less productive workers (Belorgey et al., 2006; Marelli \& Signorelli, 2010). Within this context, the increase of the efficiency due to the fact that it creates a jobless growth does not lower the unemployment rate.

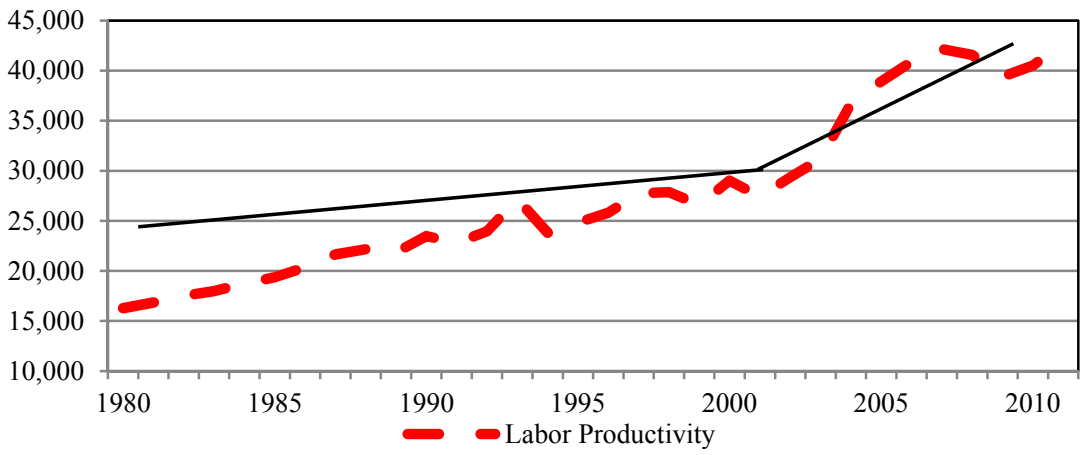

Figure 2. Aggregate labor productivity in Turkey (2011)

Source: The Conference Board, Total Economy Database. 
Within the last 10 year period, which we called the structural reform process, all of the sectors, especially industry, had to increase their efficiency in order not lose their international competitive force as a result of the global based crisis that was experienced in our economy at the time. In this process in which the employment increase remained limited, it is seen that the growth was proven to be possible rather by the increase of labour efficiency. In short, the manufacturers; in line with the goal of boosting their competition force for international trade, generally resorted to decreasing their labour costs. Therefore, they followed policies aimed at increasing the efficiency per worker or sustaining production by putting their employees to work for extended durations or rather than employing a large number of workers, they opted to employ a growth strategy by making the same amount of production with less workers. While this situation contributed to economic growth, it also had a negative impact on employment and joblessness.

Table 1. Turkish economy's labour productivity

\begin{tabular}{lcc}
\hline & Per Hour Worked & Per Person Employed \\
\hline $1980-1989$ & 3.37 & 2.81 \\
$1990-1999$ & 2.63 & 2.23 \\
$2000-2011$ & 4.69 & 4.22 \\
$2002-2011$ & 5.16 & 4.71 \\
\hline
\end{tabular}

Source: From The Conference Board Total Economy Database.

In the post 2001 period where the reforms were considerably accelerated, while the economy was registering a growth rate of approximately $4 \%$, the labour efficiency also increased dramatically compared to the earlier periods and an increase of $5.2 \%$ in efficiency per working hour and an increase of $4.8 \%$ in efficiency per working person was achieved. This situation helps to explain the fact that despite the presence of the positive growth figures in the Turkish economy, the growth process remained ineffective to increase employment and decrease joblessness immediately.

Another reason that the enterprises do not demand labour despite the economic growth is the uncertainties towards the expansion of the economy regarding whether it would be long term or short term and the existence of legal protection suits that make it more difficult to decrease labour in the case of a possible shrink in demand. The enterprises, in economies where there are regulations such as high severance pays and strict labour laws, that are designed to protect the employment, are valid and in effect, make it difficult to make decisions regarding the employment level according to the domestic and international conjuncture (World Bank, 2006). An employer who can increase his/her demand for labour under the influence of the expansion in the economy, and also feels anxious about the economic conditions in the future, is also aware that in the stagnant periods where the demand for the produced goods and services inclines and the production capacity reduces, it is not easy to reduce the workforce. In this context, the enterprises, according to the latest developments in the economy, may experience a delay between the decision regarding the recruitment and laying off and may be hesitant to recruit new workers (TEPAV, 2007).

The recent developments in the global free market economy force the public sector to reorganise. Privatisation moves constitute an essential part of the reform programs in developing or developed economies (Sheshinski \& López-Calva, 2003). In this context, in order to form a market economy based on competition, in order to improve the capital market and in order to gain the inert savings to the economy, it is an essential point to privatise public institutions and enterprises that lost their functionality over time, working with low efficiency and extreme labour costs. From this point forward, both by improving the public institutions deemed necessary and by privatising the institutions that lost their functionality over time, it is possible to add the inert savings into the country. The privatisation of the typically over-expanded and low performance publicly owned institutions would cause the costs, which are called task losses in the literature and which form a strain on the public sector, to decrease and by the increase of the efficiency in the economy, would cause investments to boost in time (Kikeri et al., 1992). Such enterprises are by their public nature generally protected from the competitive environment (especially the lack of bankruptcy risk and the fact that their losses are reimbursed from the general budget), employ too many workers, their wages are relatively high compared to those working in the private sector and their labour contracts are quite strict (Kikeri, 1998). Such characteristics of public institutions cause low efficiency and extreme labour costs. Contrary to general opinion, the realisation of the privatisations would positively influence the economy. Therefore, enabling new investments both in the enterprise level and sector level and providing a dynamic growth would create new job opportunities. However, the layoffs that are usually experienced in the public institutions after privatisation movements by the definition of the reorganisation may 
cause an increase in the unemployment rate for a certain period according to the characteristics of the economies. But with the commencement of the production of the privatised enterprises in higher rates of efficiency, the foretold effect would be in a positive direction in the long run (Hachette \& Schwarzenberg, 1993; Kikeri, 1998; Barnett, 2000; Cook \& Uchida, 2003). Also, by abandoning unnecessary subventions, decreasing the indebtment need of the public sector thus by decreasing the debt strain of the state, the state is enabled to allocate more resources to its own tasks such as education, health and infrastructure services, therefore contributing to economic growth (Sheshinski \& López-Calva, 2003).

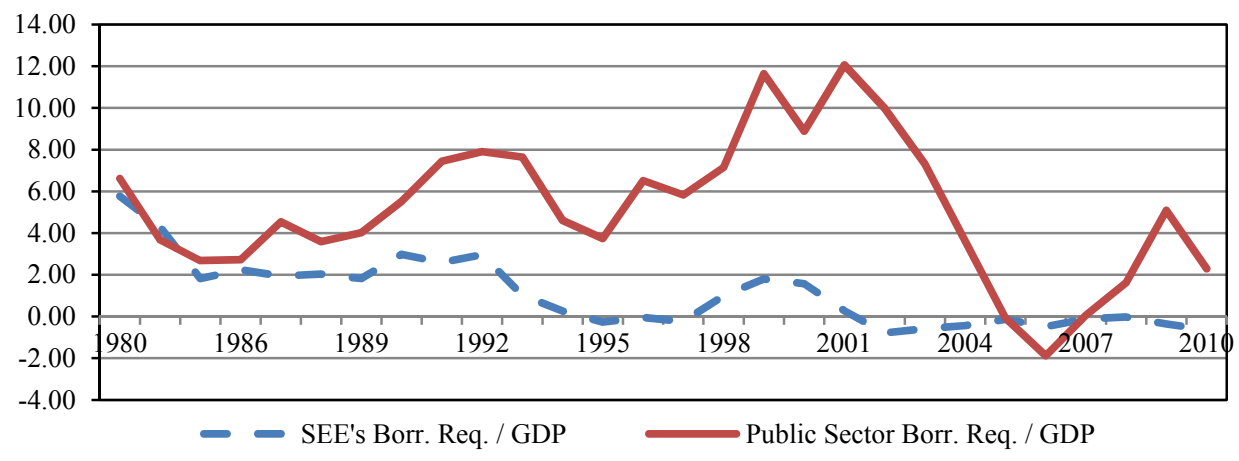

Figure 3. Public sector borrowing requirement / GDP

Source: Ministry of Development.

By the implementation of the privatisation program, as an integral element of the reform package, solely within the reform period, around 10,376 million USD of income have been generated by the privatisation of approximately 40 enterprises including Karabük Demir Çelik, TÜPRAŞ, Petrol Ofisi, Erdemir, Sümer Holding, and SEKA. However, while approximately 48,600 people were employed by those mentioned enterprises before privatisation, this situation leads to a layoff of 18,100 employees thus bringing down the total of employers to 30,500 after privatisation. (Note 4) Within this context, a stable growth by the financial discipline approach was secured by the implementation of privatisation from the viewpoint of avoiding over employment in the public sector and saving the SEEs (State Economic Enterprise) from the debt strain in addition to providing resources to the state. However, due to the severances that those indicated implementations caused, the expected level of employment failed to be reached.

Before assessing the elements regarding the fact of raising jobless levels despite increasing employment rates, the probable structural change that would occur within the labour market should be analysed and the disintegration in the agriculture sector within this process and the movement of the labour coming from this sector towards the non-agricultural sectors should also be broken down.

The virtual decrease in the share of the agriculture sector within the total revenue causes the reshaping of the distribution of the resources within the sectors (Mundlak et. al, 1989). However, such a reorganisation of the inter-sectorial resources is quite costly and thus it is not a momentary action. As a result of such an action, great deficits in the wage rates between the sectors occur in parallel to the economic growth. Within this context, at least in the initial stages of economic growth, the formation of the capital is virtually much more rapid in the urban production (manufacturing) sector than the agriculture sector (Bencivenga \& Smith, 1997). Due to the growing deficit of the real incomes between the urban and rural areas and because the income of countryside is rendered insufficient to meet needs, an increase in migration from the low efficient agricultural job opportunities to the cities that house industrial activities with high productivity is observed (Todaro, 1969). For this reason, because the level of employment raise experienced the non-agricultural sectors in parallel to the economic growth is insufficient to absorb the upcoming labour force from the disintegrating agricultural sector or in the case that the qualifications and skill levels cannot meet the requirements of employment that was reached by economic growth, the unemployment levels may raise even when there is a certain economic growth on the move (Todaro, 1969; Bencivenga \& Smith, 1997). In addition, the insufficient qualifications and skill level of the labour force that emerge from the agricultural sector that cannot meet the requirements of the labour market thus increase unemployment, even if the employment opportunities are increased enough, is not the only problem that is caused by the disintegration, occurring in the agriculture sector. The increasing number of jobless and poor people in the cities with the disintegration, occurring in the agriculture sector, also accelerates the urban population growth rate thus increasing the demand for urban services. While this situation increases the public 
expenditure on one hand, it fails to increase public revenues, due to the fact that raising the unemployment and underemployment prevent the revenues and taxes that are necessary to provide such services to be collected (Frank, 1968).

While the economic structure of Turkey entered a significant period of change within the structural reform process, the labour markets also entered into a transformation process parallel to such a change. In this period, the sectorial movement of the labour markets showed a tendency to non-agricultural sectors from the agricultural sectors. While Turkey, which then comprised $70 \%$ of its total population, produced $32 \%$ of the total revenue in 1970 , today we see that the country population that comprises $30 \%$ of the general population can produce only $9 \%$ of the revenue. In this case, it is observed that the agricultural labour that cannot subsist itself moves to non-agricultural sectors.

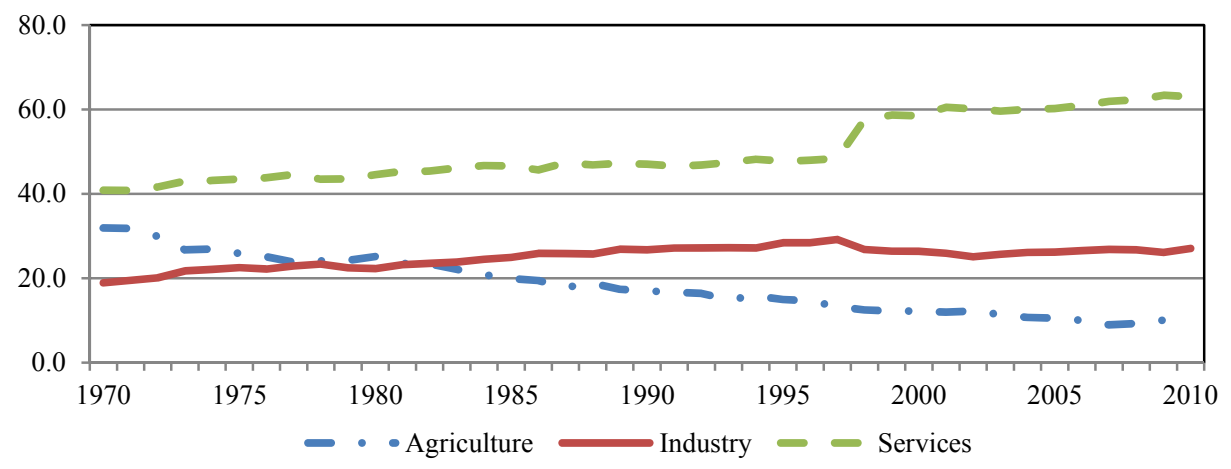

Figure 4. Sectoral Breakdown of the gross domestic product

Source: Turkstat and SPO's database.

The employment level of the Turkish labour market based on the economic activity branches are seen in Figure 5. According to this, while the agricultural weight of the labour comprises around $36 \%$ of the total labour force $(7,769)$ based on the data from 2000 , this ratio is observed to decline to $25 \%(5,683)$ At the same time, while the agricultural sector suffered a loss of 2,086 in employment in the process, the fact that although the non-agricultural sectors (industry and services) created 3,102 new jobs, it is seen that they failed to meet the loss indicted above. In short, it seems that when this mass, comprised of 2,086 hidden unemployed and openly unemployed people emerged from the agriculture sector during the last 10 years, left the agricultural sector, employment decreased. In this case, the new jobs generated by the non-agricultural sectors cannot be the solution to the unemployment problem due to the employment decline occurring in the agricultural sector. Therefore, in our country, where the share of the agricultural sector within the total employment is high, the rapid decline experienced in the agricultural sector may cause general employment levels to drop and increase unemployment in the short term despite the economic growth.

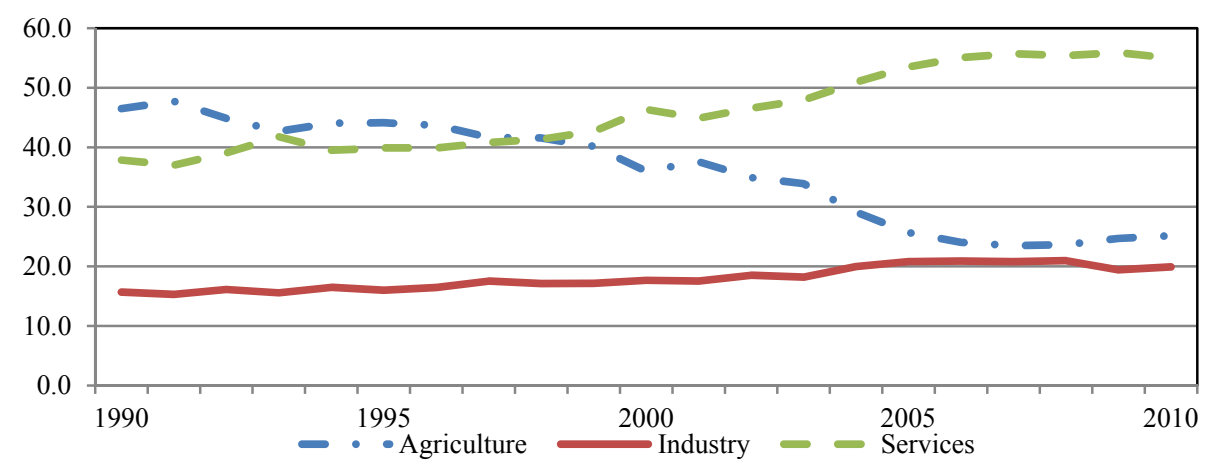

Figure 5. Employment by sectors

Source: Turkstat, from Labour Force Statistics Database.

Registering a sustainable growth performance depends on significantly decreasing the public deficits using the financial discipline concept, decreasing the need for public borrowing and correspondently lowering the interest 
based debt strain on the budget. Securing a public financing balance comes forward as being one of the most basic elements to create economic stability and high growth rate. Within this concept, one of the most prominent obstacles in front of sustaining stability in public financing is early retirement. Early retirement applications are considered to be policy tools by the governments of the economies that suffer from high unemployment rates and they can be used to bring about the solution of the unemployment problem (Laczko et al., 1988). The late retirement of the labour in an economy and pressure to work for longer periods reduces the number of job opportunities that are available for the new labour force who would be employed instead of them when they retire (especially for young people) (Gruber et al., 2009). For a worker not to retire and still be in active service means that there is no recruitment for a jobless person and this increases unemployment. However, by the early retirement implementations, the social security institutions rendered to be deprived from the premium incomes and at the same time, generating deficit by being constrained to pay monthly allowances more than they receive premiums can put further strains on to the general budget. In addition to the negative effects of the early retirement implementations on the public finance balance, they cause the reduction of the highly experienced labour force (Hakola \& Uusitalo, 2005). In this context, within the scope of the social security reform that was made after 2001, the early retirement problem, which was one of the most important reasons for the disruption of the balance of the budget balance, was improved by the regulations. The social security institutions of the pre-2001 period in addition to being deprived from premium incomes due to early retirement had to pay monthly allowances for longer than the duration that they receive premiums. This situation, by causing the social security institutions to generate deficits thus increasing the public deficit, had a negative impact on economic growth. Therefore, although the capability to create new jobs was put into decline by the reforms made in this direction, the experienced and work capable labour now benefits for longer periods. Also, when Turkey is considered to have a young population, it is normally expected from a social security system to make positive contributions to the economy by deposition of the funds with the premiums instead of registering deficits, which may provide a job creating growth in the long term.

The fact that the indicated increase within the economies where the growth boosted, causes the import and foreign trade deficit leads to the fact that instead of meeting the domestic demand with domestic product and services they are provided from foreign countries. In addition, procuring a major part of the inputs that are used for production by imports proves that Turkey is a foreign source dependant on production meaning that the generated resources flow outside by import activities. This situation means a raise in the production of the exporting country thus boosting its employment levels. Naturally, process is reversed for the importing country, decreasing employment. While this would mean a kind of "import of joblessness", at the same time the joblessness can also turn into a very serious structural problem in the case that foreign trade deficit becomes persistent.

\section{The Impact of Economic Growth on Unemployment in Turkey}

\subsection{Model, Dataset and the Implemented Econometric Method}

In this study, the relationship between the economic growth and unemployment in the Turkish economy is examined econometrically. For the stipulation of the said relation, the time period from 1980-2011 in Turkey was used. As is discussed in the literature, it is planned to analyse whether or not there is a breaking point between the economic growth and unemployment within the reform process made after 2001 by structural breaking test and as the result, the examined periods were divided into two sub periods, consisting of 1980-2001 and 2002-2011. Accessibility of data was the definitive factor in selecting of the time periods to be examined. In the study, the relationship between two variables was handled annually due to the difficulties experienced in obtaining the data of the said 1980-2001 and 2002-2011 periods but quarterly time sequences were used for the 2002-2011 period, which constitutes the base of the study. The data of the application is comprised from the growth rates of the Turkey Statistical Institute (TSI)'s 1987 based fixed prices and GDP figures as well as the data of the time sequences belonging to people above 15 years of age. Logarithmically $\left(\operatorname{lnGDP}_{t}\right.$ and $\left.\operatorname{lnUNE} \mathrm{E}_{\mathrm{t}}\right)$ were taken in both variables taking part in Model 1. Since the unit root, co-integration and error correction analyses are discussed in a detailed manner in the literature, they will be briefly mentioned in this study.

$$
\ln U N E_{t}=\beta_{0}+\beta_{1} \ln G D P_{t}+\varepsilon_{t}
$$

$\operatorname{lnGDP}_{\mathrm{t}}$ (Gross Domestic Product) shows the logarithm of real GDP variable and $\ln \mathrm{UNE}_{\mathrm{t}}$ (Unemployment), indicates the logarithm of unemployment. Furthermore, $\varepsilon_{t}$ is the error term.

If we take a look from the viewpoint of the expected values regarding the indicators of the coefficients of the model; the general expectation is increasing the GDP and by influencing the investments and production, having a positive impact on the unemployment (joblessness) however, as it has been discussed in the literature, the value 
that the $\beta_{I}$ would get is expected to be negative for the 2002-2011 sub-period with the assumption that the economic growth reached in the structural reform process in the post 2001 period inclined towards growth without creating jobs or decreasing unemployment.

In the study, for the stipulation of the relationship between the unemployment rate and the GDP, and to examine the characteristics of the time sequence of each variable, it was first tested whether or not the sequences are stable and, if they are, to what extent they are stable, using the Augmented Dickey-Fuller (ADF) and Phillips-Perron (PP) unit root tests. The common problem that is encountered in traditional unit root tests (ADF, $\mathrm{PP}$ ) is that such tests do not take the probability of structural break into consideration.

Another point that was emphasised during the study is the fact that in the case that structural breaks in time sequences occur, the standard unit root tests provide results with variances. So, naturally, unit root tests with structural break would be much suitable for such time sequences. The time sequences are not generally stable (they contain unit root). For this reason, whether or not the indicated unit root is generated because the sequence is really not stable or it is based on a structural break should be examined. In this context, whether or not there is a structural break available between two variables were tested using Zivot-Andrews (1992) structural break test.

By determining that the co-integration levels of the variables are the same thus they are stable in the same degree, as the result of the unit root tests, co-integration analysis was made and therefore the existence of a long term relationship between the variables was dissected. The presence of a co-integration between the variables was tested using Johansen co-integration test.

Finally, the presence of a balance between the variables GDP and unemployment in the short term can be analysed using the error correction method. In order to evaluate the short term dynamics between the indicated variables, Error Correction Method was utilised.

\subsection{Empiric Analysis and Findings}

In order to extract econometrically significant relations between the variables, the sequences that are being examined should be stable. For this reason, the first step to take should be testing the time sequences that are used in the model to discover whether or not they are stable. Within this context, principally, the stability of the variables has been tested in this study. For testing whether or not the time sequences are stable, the Augmented Dickey-Fuller (ADF) test which was developed by Dickey and Fuller and Phillips-Perron (PP) unit root tests were utilised. The results of the root tests can be seen in Table 2 .

The parenthetical figures are the lag figures for the variables and they are determined as the minimum lags without having autocorrelation according to Schwartz Information Criterion (SIC) for ADF test and Newey-West Bandwidth criterion for PP test. When the results of ADF and PP tests in Table 3 are examined, it can be observed that the sequences are not stable at the $1 \%$ significance level, meaning that they contain a unit root. As a result, the first variances of each test were taken. Therefore, it is also seen that the variables became stable.

Table 2. The results of unit root tests

\begin{tabular}{lllll}
\hline \multirow{2}{*}{ Variables } & ADF Tests & PP Tests \\
\cline { 2 - 5 } & Level & 1st Difference & Level & 1st Difference \\
\hline $\ln G D P_{t}$ & $0.674907(0)$ & $-5.421808(0)$ & $1.293537(5)$ & $-5.426015(2)$ \\
Critical Values & -3.670170 & -3.679322 & -3.670170 & -3.679322 \\
LnUNE_SA & $-1.276229(0)$ & $-5.655097(0)$ & $-1.220361(2)$ & $-5.862765(6)$ \\
Critical Values & -3.670170 & -3.679322 & -3.670170 & -3.679322 \\
\hline
\end{tabular}

Note: The numbers in the parentheses show the lag length.

At this stage, in order to study the stability analysis of the sequences completely, the presence of possible breaks within the series should be examined. The fact that there is a breaking in the degree and the inclination of a time sequence suggests that a break-up in both degree and the inclination occurs after a certain period $\left(\mathrm{T}_{\mathrm{b}}\right)$ (Sevuktekin \& Nargeleçekenler, 2010). In the time sequence regarding the unemployment variable shown in Table 5 it can be observed that there is a change in level and inclination (thus break-up) after 2001. The cranked straight line in Figure 5 reflects the improvised trend line. 


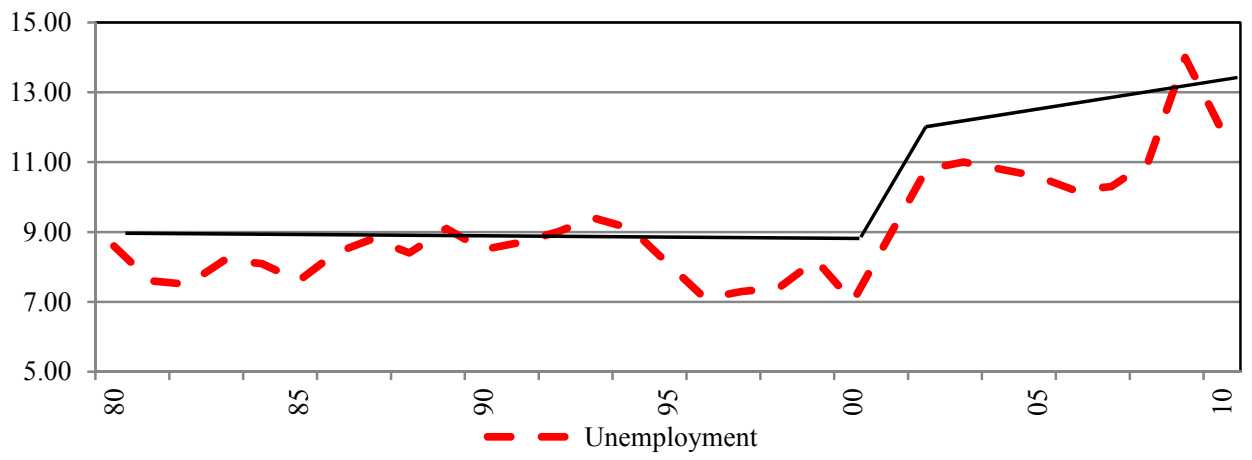

Figure 6. Change in level and inclination of the unemployment time sequence

The Zivot-Andrews approach, which suggests that the exact moment of break-up is unknown and occurs at any point, aims to estimate the reflection of the relative change (break-up) that gives the most weight for the alternate hypothesis that indicates the trend stability.

Table 3. The results of zivot-andrews unit root test

\begin{tabular}{lll}
\hline Variables & Min. t-Statistic & $\mathrm{T}_{\mathrm{b}}$ (Break Point) \\
\hline LnUNE_SAt & $-4.431483(1)$ & 2001 \\
ZACritical Values & & \\
$5 \%$ & -4.93 & 2001 \\
LnGDP $t$ & $-3.991551(1)$ & \\
ZA Critical Values & & \\
$5 \%$ & -5.08 &
\end{tabular}

Note: The numbers in the parentheses show the lag length which is selected for ZA Breakpoint test. ZA critical values were taken from Zivot and Andrews (1992).

The results of Zivot-Andrews (1992) unit root test that was applied to the variables are presented in Table 3. The result of the ZA test points out the year of 2001 as the structural break up period in the model. Since the extracted test statistics are lower than the critical value at a significance level of $5 \%$, the hypothesis suggesting that it became stable by the 2001 centred break up is rejected. Therefore, the main hypothesis pointing out the presence of unit root in the series without structural break up is accepted. According to the ZA unit root test, the presence of the hysteria effect for unemployment has also been found. Within this context, the results of ZA test that suggests a structural break up in 2001 also points out the period where one of the most important crisis' of Turkish economy has ever experienced occurred. Therefore, after the examinations of the unit roots of the sequences that belong to variables are completed, there is no obstacle left to moving onto the co-integration tests.

The first step in the Johansen Method is to determine the lag length. For this reason, after confirming that the sequences are stable in the same level, and before initiating the Johansen co-integration test, the optimum lag length should also be determined. For determining the convenient lag length of the studied variables, VAR model was utilised. In order to provide the optimum lag length, the LR (Likelihood Ratio), AIC (Akaike Information Criterion), SIC (Schwarz Information Criterion), FPE (Final Prediction Error) and HQ (Hannan-Quinn Information Criterion) information criterions were implemented. According to the estimation results of the minimum lag lengths extracted from this model, it is seen that SIC, LR, FPE, AIC and HQ values provide the minimum values for 1 lag. Therefore, it was decided to determine the lag length as 1 in this study.

After determining the convenient lag length, the Johansen co-integration test was analysed. The results of the Johansen co-integration test that was conducted for the lag length of "1" are given in Table 4. The results of Table 4 indicate the Hypothesis $\mathrm{H}_{0}$, which suggests that there is no co-integration between the given variables for the (1980-2001 and 2002-2011) periods in the maximum latent value of $\left(\lambda_{\max }\right)$, and $5 \%$ significance levels of trace test statistics $\left(\lambda_{\text {trace }}\right)$, is rejected and there is a co-integration vector present between the variables. According to this, there is a co-integration between the indicated variables, meaning that the presence of a long term relationship between the sequences that are valid both for maximum latent value test and trace test is apparent. 
Table 4. The results of Johansen co-integration test

\begin{tabular}{|c|c|c|c|c|c|}
\hline \multirow[t]{6}{*}{$1980-2011$} & Null Hypothesis & $\begin{array}{l}\text { Alternative } \\
\text { Hypothesis }\end{array}$ & $\begin{array}{l}\lambda_{\text {trace }} \\
\text { Statistic }\end{array}$ & Critical Value $\% 5$ & Prob.* \\
\hline & $\mathrm{r}=0$ & $r \geq 1$ & 15.19537 & 15.49471 & 0.0554 \\
\hline & $\mathrm{r} \leq 1$ & $r \geq 2$ & 2.221817 & 3.841466 & 0.1361 \\
\hline & Null Hypothesis & $\begin{array}{l}\text { Alternative } \\
\text { Hypothesis }\end{array}$ & $\begin{array}{l}\lambda_{\max } \\
\text { Statistic }\end{array}$ & Critical Value $\% 5$ & Prob.* \\
\hline & $\mathrm{r}=0$ & $r \geq 1$ & 12.97355 & 14.26460 & 0.0791 \\
\hline & $\mathrm{r} \leq 1$ & $r \geq 2$ & 2.221817 & 3.841466 & 0.1361 \\
\hline \multirow[t]{6}{*}{$1980-2001$} & Null Hypothesis & $\begin{array}{l}\text { Alternative } \\
\text { Hypothesis }\end{array}$ & $\begin{array}{l}\lambda_{\text {trace }} \\
\text { Statistic }\end{array}$ & Critical Value $\% 5$ & Prob.* \\
\hline & $\mathrm{r}=0$ & $r \geq 1$ & 18.42176 & 12.32090 & 0.0042 \\
\hline & $\mathrm{r} \leq 1$ & $r \geq 2$ & 0.004959 & 4.129906 & 0.9540 \\
\hline & Null Hypothesis & $\begin{array}{l}\text { Alternative } \\
\text { Hypothesis }\end{array}$ & $\begin{array}{l}\lambda_{\max } \\
\text { Statistic }\end{array}$ & Critical Value $\% 5$ & Prob.* \\
\hline & $\mathrm{r}=0$ & $r \geq 1$ & 18.41680 & 11.22480 & 0.0023 \\
\hline & $\mathrm{r} \leq 1$ & $r \geq 2$ & 0.004959 & 4.129906 & 0.9540 \\
\hline \multirow[t]{6}{*}{ 2002:1-2011:4 } & Null Hypothesis & $\begin{array}{l}\text { Alternative } \\
\text { Hypothesis }\end{array}$ & $\begin{array}{l}\lambda_{\text {trace }} \\
\text { Statistic }\end{array}$ & Critical Value $\% 5$ & Prob.* \\
\hline & $\mathrm{r}=0$ & $r \geq 1$ & 107.9110 & 15.49471 & 0.0001 \\
\hline & $\mathrm{r} \leq 1$ & $r \geq 2$ & 4.536112 & 3.841466 & 0.0332 \\
\hline & Null Hypothesis & $\begin{array}{l}\text { Alternative } \\
\text { Hypothesis }\end{array}$ & $\begin{array}{l}\lambda_{\max } \\
\text { Statistic }\end{array}$ & Critical Value $\% 5$ & Prob.* \\
\hline & $\mathrm{r}=0$ & $r \geq 1$ & 103.3748 & 14.26460 & 0.0000 \\
\hline & $\mathrm{r} \leq 1$ & $r \geq 2$ & 4.536112 & 3.841466 & 0.0332 \\
\hline
\end{tabular}

Note: *MacKinnon-Haug-Michelis (1999) p-values.

When the results in Table 4 are examined, it is seen that there is more than one co-integrated vector between the sequences that are at $5 \%$ of significance level for both latent value and trace statistics. Therefore, it can be said that there is a long term relationship between GDP and unemployment regarding the relevant term. For the 1980-2001 period, the hypothesis, formulated as $\lambda_{\text {trace }}=18.42>12.32$ and $\lambda_{\max }=18.41>11.22$; and for the 2002-2011 period $\lambda_{\text {trace }}=107.91>15.49$ and $\lambda_{\max }=103.37>14.26, \mathrm{r}=0$ was rejected for both test values, meaning that the given variables are co-integrated. However, the results of the analysis also suggests that there is no long term co-integration relationship between the variables in question in long term.

When the co-integration relationship is normalised according to the unemployment variable for the 1980-2001 period, the relationship between variables is shaped as follows:

$$
\begin{array}{r}
\text { LnUNE_SA }=\text { - } 0,343 \operatorname{LnGDP} \\
(0,0274)
\end{array}
$$

When the co-integration relationship is normalized according to unemployment variable for the terms; 2002:Q1-2011:Q4, the relationship between variables are shaped as follows:

$$
\begin{aligned}
\text { LnUNE_SA }= & 2,199 \text { LnGDP } \\
& (0,0979)
\end{aligned}
$$

When the normalised co-integration vectors are examined, (2 and 3) along with the structural reform process, implemented in the post 2001 crisis period, it can be summarised that the effects of the economic growth experienced in the Turkish economy on the labour market remained limited and thus while the pre-reform economic growth decreased the unemployment rate, in the post 2001 period this correlation occurred in the opposite direction.

The presence of a co-integration between the variables indicated here suggests that there is a long term balance relation between the two series. That means that the co-integration is analysing a long term relationship. However, no equilibrium at all between two given variables in the short term is also a probability. The Error Correction Model indicates for how long the variances that occur in the short term are corrected. However, in order for the error correction mechanism to function, the error correction co-efficient is expected to have a 
negative mark as well as being less than 1. The negative mark of error correction co-efficient suggests a movement towards the balance in the case that there is a variance from the balance, and the coefficient being less than 1 indicates that there is a balance in the system (Bozkurt, 2007). After witnessing the presence of a long term relationship between the variables, the existence of a short term relationship is analysed by estimation of the error correction model.

The error correction model that is utilised in this study is given below;

$$
\Delta U N E_{-} S A_{t}=\beta_{0}+\sum \beta_{1} \Delta U N E_{-} S A_{t-i}+\sum \beta_{2} \Delta G D P_{t-i}+\sum \beta_{3} \Delta E C_{t-1}+\varepsilon_{t}
$$

$E C_{t-1}$ that is included in the model indicates the first lagged value of the error term, extracted from the long term relationship and is called error term.

Table 5. VECM- Results of vector error correction estimates

\begin{tabular}{ll}
\hline$\Delta($ UNE_SA $=$ & $-0.074 \mathrm{EC}_{\mathrm{t}-1}+0.3827 \Delta\left(\mathrm{UNE}_{-} \mathrm{SA}_{\mathrm{t}-1}\right)-0.0060 \Delta\left(\mathrm{GDP}_{\mathrm{t}-1}\right)-0.0202$ \\
& $(-1.31)(2.43)(0.69)(-0.21)$ \\
& $\mathrm{R}^{2}=0,90 \mathrm{~F}=108,7$ \\
\hline
\end{tabular}

Note: The numbers in the parentheses show t-statistics.

After using the error correction mechanism that was established between the sequences, the data, shown in Table 5 was obtained. According to those findings; the fact that the $\mathrm{R}^{2}=$ value is 0.90 suggests that the power of the model to explain the change in unemployment is significantly high. Also, it is understood that the error term coefficient that was extracted from the model, in which the unemployment variable turned to be independent variable as the result of the error correction mechanism, is -0.08 . As expected, the error correction coefficient resulted in a negative value and is less than " 1 ".

The balance error term coefficient regarding the unemployment equation is anticipated as -0.08 . This coefficient is a statistically significant and evaluable magnitude. According to this result, it can be concluded that $8 \%$ of an imbalance at the unemployment rate that was determined as the result of the economic growth goes away within a year or is corrected. Therefore, it can be deducted that after the $12.5 \mathrm{term}$, the variances would come to a balance.

\section{Conclusion and Evaluation}

With the structural reforms that were put into implementation as the result of its crisis experiences, Turkey achieved considerable success in its economy. In this period, while securing high and consistent growth, it also succeeded in bringing inflation down to single digits. At the same time, Turkey got rid of the disease of financial indiscipline that threatened economic as well as political stability and which it had struggled to solve for many years and the budged discipline was also widely provided. By the regulations, the demand for the debts of the state that became chronic were also largely reduced. At the same time, the banking sector, which is pivotal both for the financing of the growth and the strength of the economy, was restored to a healthy state by the regulations and the supervisions and went through a serious test with the recent crisis. Despite this, the rate of employment has not been decreased in parallel to the growth and climbed to a level even proceeding the pre-crisis period.

In the study, the relationship between the economic growth and unemployment concept in the Turkish economy was examined econometrically. In order to determine the direction and size of the relationship between the given variables; Johansen co-integration and error correction model was utilised. The results of the co-integration test indicate that the impact of the economic growth stimulated in the Turkish economy within the structural reform process on the labour market that had been limited and therefore, while the growth levels reached prior to the reform movements decreased the unemployment levels, such a correlation occurred in a retrograde way. The short term relationship between the two given variables was analysed using an error correction model. According to this, the error term co-efficient was found to be a statistically significant and evaluable magnitude and it is observed that the percentage of the imbalance of the unemployment level that is determined as the result of the economic growth disappears or moves into balance again within a year.

As a result of the policies followed along with the structural reform process in Turkey, the state ceased to be considered as a source of employment and the road for the private sector was paved to be a spearhead of economic growth. However, although Turkey, which failed to create a sufficient and qualified workforce even under stable growth conditions, improved its economy in many aspects it was unable to produce a viable solution to the unemployment problem. In spite of this, while the primary goal is protecting macroeconomic stability and avoiding the regulations that contrast with the aims stipulated in the economic reforms, it is also expressed that 
in the case that the competitive force of the Turkish economy is increased and a production level with high added value is reached, the jobless growth, which is considered to be a temporary process, would decrease the level of unemployment in the long term.

\section{References}

Acar, O. (2008). Türkiye Ekonomisindeki Yapısal Dönüşümün Dinamikleri. Uluslararası Ekonomik Sorunlar Dergisi, 31, 30-39. Retrieved from http://www.mfa.gov.tr/data/Kutuphane/yayinlar/EkonomikSorunlarDergisi/sayi31/Ozan\%20ACAR.pdf

Aghion, P., \& Howitt, P. (1994). Growth and Unemployment. The Review of Economic Studies, 61(3), 477-494. http://dx.doi.org/10.2307/2297900

Ataman, B. C. (2006). Discussions on Unemployment in Turkey in the Period of 2000-2005. Iktisat Işletme ve Finans, 21(239), 93-107. http://dx.doi.org/10.3848/iif.2006.239.4644

Barnett, S. (2000). Evidence on the Fiscal and Macroeconomic Impact of Privatisation. IMF Working Papers, No:00/130.

Belorgey, N., Lecat, R., \& Maury, T. (2006). Determinants of Productivity Per Employees: An Empirical Estimation Using Panel Data. Economics Letters, 91(2), 153-157. http://dx.doi.org/10.1016/j.econlet.2005.09.003

Bencivenga, V. R., \& Smith, B. D. (1997). Unemployment, Migration, and Growth. Journal of Political Economy, 105(3), 582-608. http://dx.doi.org/10.1086/262083

Bhattacharya, B. B., \& Sakthivel, S. (2004). Economic Reforms and The Jobless Growth in India in the 1990s. Institute of Economic Growth. IEG Discussion Paper Series, No. 245/2004.

Boyer, R., \& Petit, P. (1981). Employment and Productivity in the EEC. Cambridge Journal of Economics, 5(1), 47-58.

Bozkurt, H. (2007). Zaman Serileri Analizi. Bursa: Ekin Kitabevi.

Caballero, R. J., \& Hammour, M. L. (1998). Jobless Growth: Appropriability, Factor Substitution, and Unemployment. Carnegie-Rochester Conference Series on Public Policy, 48, 51-94.

Çakmak, E., Kasnakoğlu, H., \& Akder, H. (1999). Tarım Politikalarında Yeni Denge Arayışları ve Türkiye. Istanbul: TÜSİAD Yayınları, No. TSÜAD-T/99-12/275.

Calmfors, L., \& Holmlund, B. (2000). Unemployment and Economic Growth - A Partial Survey. Swedish Economic Policy Review, 7, 107-153.

Ceylan, S., \& Şahin, B. Y. (2010). Asymmetry in the Relationship between Unemployment and Economic Growth. Doğuş Üniversitesi Dergisi, 11(2), 157-165.

Christopoulos, D. K. (2004). The Relationship between Output and Unemployment: Evidence From Greek Regions. Papers in Regional Science, 83(3), 611-620. http://dx.doi.org/10.1007/s10110-004-0198-y

Cook, P., \& Uchida, Y. (2003). Privatisation and Economic Growth in Developing Countries. The Journal of Development Studies, 39(6). 121-154. http://dx.doi.org/10.1080/00220380312331293607

Datt, R. (1994). Jobless Growth: Implications of New Economic Policies. Indian Journal of Industrial Relations, 29(4), 407-427.

Frank, C. R. Jr. (1968). Urban Unemployment and Economic Growth in Africa. Oxford Economic Papers, New Series, 20(2), 250-274.

Fulco, L. J. (1984). Strong Post-Recession Gain in Productivity Contributes to Slow Growth in Labour Costs. Monthly Labour Review, 107(12), 3-10.

Gordon, R. J., \& Clark, P. K. (1984). Unemployment and Potential Output in the 1980s. Brookings Papers on Economic Activity, 15(2), 537-568.

Gruber, J., Milligan, K., \& Wise, D. A. (2009). Social Security Programs and Retirement Around the World: The Relationship to Youth Employment, Introduction and Summary. National Bureau of Economic Research (NBER) Working Paper Series, WP No. 14647.

Hachette, D., \& Schwarzenberg, R. L. (1993). Privatization in Chile: An Economic Appraisal. An International Center for Economic Growth Publication, ICS Press.

Hakola, T., \& Uusitalo, R. (2005). Not So Voluntary Retirement Decisions? Evidence from A Pension Reform. 
Journal of Public Economics, 89(11-12), 2121-2136. http://dx.doi.org/10.1016/j.jpubeco.2004.12.001

Havlik, P., \& Landesmann, M. (2004). Structural Change, Productivity and Employment in The New EU Member States. In Economic Restructuring and Labour Markets in The Accession Countries (Chapter 1). research project commissioned by the EU DG Employment and Social Affairs, Final Report, European Commission, 1-23.

IMF Letters of Intent (all). Retrieved from http://www.tcmb.gov.tr/yeni/iletisimgm/IMFniyet.html

Kesici, M. R. (2010). In High Growth Phase of Turkey Economy Employment and Unemployment. "Is, Guc" Industrial Relations and Human Resources Journal, 12(3), 7-26. http://dx.doi.org/10.4026/1303-2860.2010.147.x

Kikeri, S. (1998). Privatization and Labour: What Happens to Workers When Governments Divest? World Bank Publications, World Bank Technical Paper No. 396.

Kikeri, S., Nellis, J. R., \& Shirley, M. M. (1992). Privatisation: The Lessons of Experience. World Bank Publications.

Kılıç, C. (2003). Türkiye'de İşsizlik ve Avrupa İstihdam Stratejisi. TíSK İşveren Dergisi, 42(1).

Laczko, F., Dale, A., Arber, S., \& Gilbert, G. N. (1988). Early Retirement in a Period of High Unemployment. Journal of Social Policy, 17(3), 313-333. http://dx.doi.org/10.1017/S0047279400016834

Marelli, E., \& Signorelli, M. (2010). Employment, Productivity and Models of Growth in the EU. International Journal of Manpower, 31(7), 732-754. http://dx.doi.org/10.1108/01437721011081572

Marelli, E., Signorelli, M., \& Tyrowicz, J. (2010). Crises and Joint Employment-Productivity Dynamics: A Comparative Perspective for European Countries. Faculty of Economic Sciences, University of Warsaw, Working Papers, No. 2010-14. http://dx.doi.org/10.1057/ces.2012.13

Ministry of Labor and Social Security. (2008). Social Security Reform. Ankara: Başbakanlık Yay. Retrieved from http://www.alomaliye.com/2008/sosguv_getirilenler.pdf

Mundlak, Y., Cavallo, D., \& Domenech, R. (1989). Agriculture and Economic Growth in Argentina, 1913-84. International Food Policy Research Institute, Research Report No.76.

O’Sullivan, A., \& Sheffrin, S. M. (2006). Economics: Principles in Action. Pearson Prentice Hall.

Padalino, S., \& Vivarelli, M. (1997). The Employment Intensity of Economic Growth in the G-7 Countries. International Labour Review, 136(2), 191-213.

Scarpetta, S. (1998). Labour Market Reforms and Unemployment: Lessons from the Experience of the OECD Countries. Inter-American Development Bank Research Department Publications, IDB Working Paper, No. 382. http://dx.doi.org/10.2139/ssrn.1817181

Sevüktekin, M., \& Nargeleçekenler, M. (2010). Ekonometrik Zaman Serileri Analizi-Eviews Uygulamalı. Nobel Yayın Dağıtım.

Seyfried, W. (2005). Examining the Relationship between Employment and Economic Growth in the Ten Largest States. Southwestern Economic Review, 32(1), 13-24.

Sheshinski, E., \& López-Calva, L. F. (2003). Privatization and Its Benefits: Theory and Evidence. CESifo Economic Studies, 49(3), 429-459. http://dx.doi.org/10.1093/cesifo/49.3.429

Telli, C., Voyvoda, E., \& Yeldan, E. (2006). Modelling General Equilibrium for Socially Responsible Macroeconomics: Seeking for the Alternatives to Fight Jobless Growth in Turkey. METU Studies in Development, 33(2), 255-293.

TEPAV. (2007). İkinci Nesil Reform Sürecinin Öncelikleri. Ankara, Ağustos 2007. Retrieved from http://www.tepav.org.tr/tur/admin/dosyabul/upload/onceliklerraporu.pdf

Todaro, M. P. (1969). A Model of Labor Migration and Urban Unemployment in Less Developed Countries. The American Economic Review, 59(1), 138-148.

World Bank. (2006). Turkey Labour Market Study. Documents of the World Bank, Report No. 33254-TR. $\begin{array}{llll}\text { Retrieved } & \text { April } & 14, & \\ & 2006 & \text { from }\end{array}$ http://www-wds.worldbank.org/external/default/WDSContentServer/WDSP/IB/2006/09/15/000310607_20 060915143444/Rendered/PDF/332540TR0Labor1ver0P07918901PUBLIC1.pdf

Yılmaz, Ö. G. (2005). Türkiye Ekonomisinde Büyüme ile İşsizlik Oranları Arasındaki Nedensellik İlişkisi. 
Ekonometri ve Istatistik, 2(1), 63-76.

Yüceol, H. M. (2006). The Dynamics of Unemployment and Growth in the Turkish Economy. Íktisat İsletme ve Finans, 21(243), 81-95. http://dx.doi.org/10.3848/iif.2006.243.5524

Zivot, E., \& Andrews, D. W. K. (1992). Further Evidence of Great Crash, the Oil-Price Shock and the Unit Root Hypothesis. Journal of Business and Economic Statistics, 10(3), 251-270. http://dx.doi.org/10.1198/073500102753410372

\section{Notes}

Note 1. Although this process began in 1999, political instabilities due to the fact that the ruling government was a coalition and delays occurred in structural reforms such as the inability to privatise some of the public institutions rendered the economy to fall into crisis once again in 2000-2001. The differences in views within the coalition government, experienced on subjects such as enclosure of the current funds and privatisation rendered the decision making process ineffective and became a major factor in the failure to reach the anticipated success from the reforms. For this reason, the date of commencement is considered to be 2001 due to the acceleration of the reformist movements after the newly experienced crises of 2001.

Note 2. While the GDP in 2001 was -5.7 and the rate of unemployment: was 8.4, the GDP in 2011 was 9.6 and the rate of unemployment: registered as $9.8 \%$. Please see the TSI database of workforce and national calculation.

Note 3. Response to the motion of the question (15.05.02-31464), for detailed information. http://www2.tbmm.gov.tr/d21/7/7-6739c.pdf

Note 4. Turk-Is, Reports: Privatisation and its consequences, (only the institutions, privatised between 1999-2006 are included). Retrieved http://www.turkis.org.tr/source.cms.docs/turkis.org.tr.ce/docs/file/MicrosoftWord_\%F6zellestirmeler.pdf 